\title{
PENGARUH KUALITAS PELAYANAN DAN FASILITAS PERPUSTAKAAN TERHADAP KEPUASAN SISWA SMAN 1 PEKANBARU
}

\author{
Maryatul Asyro ${ }^{1)}$ \\ Rr. Sri Kartikowati ${ }^{2)}$ \\ Marzuki ${ }^{3}$ \\ 1) Post Graduate Student of Riau University \\ 2) Lecturer of Education Management Study Programme PPS University of Riau \\ ${ }^{3)}$ Lecturer of Education Management Study Programme PPs University of Riau
}

\begin{abstract}
The objective if this research is to understand the effect of library service and facilities quality students satisfactions he type of this research is quantitative research where the example was taken from 978 students withdrawing simple sampling randomly on 91 students that visited library of SMAN 1 Pekanbaru. The data collection techniques were using documentation and questionnaires then analyzed by quantitative. The result showed that multiple regression test gave positive and significant result between services quality variables and library facility gave a huge influence on students' satisfaction. The quality of services and library facilities aprooved stimunieously to the students' satisfaction
\end{abstract}

Keywords: Service Quality, Facility Library, Students Satisfication

\begin{abstract}
ABSTRAK
Penelitian ini bertujuan untuk mengetahui pengaruh kualitas pelayanan dan fasilitas Perpustakaan terhadap kepuasan siswa. Jenis penelitian ini adalah deskriptif kuantitati. Populasi penelitian adalah siswa SMA N 1 Pekanbaru yang berjumlah 979 siswa. Penarikan sampel menggunakan simple random sampling, sehingga menghasilkan sampel sebanyak 91 siswa. Teknik pengumpulan data yang dipakai adalah kuesioner dan dokumentasi, Data yang diperoleh dianalisis menggunakan analisa regresi berganda. Berdasarkan Hasil penelitian, menunjukkan bahwa dari persamaan regresi berganda membuktikan adanya pengaruh yang positif dan signifikan antara variabel kualitas pelayanan dan variabel fasilitas perpustakaan terhadap kepuasan siswa. Dari Hasil pengujian uji t (Uji Partial) menunjukkan variabel kualitas pelayanan berpengaruh signifikan terhadap kepuasan siswa. variabel fasilitas perpustakaan berpengaruh signifikan terhadap kepuasaan siswa. Kualitas Pelayanan dan Fasilitas Perpustakaan berpengaruh secara bersama-sama (simultant) terhadap Kepuasan Siswa SMA Negeri 1 Kota Pekanbaru
\end{abstract}

Kata Kunci: Kualitas Pelayanan, Fasilitas Perpustakaan, Kepuasan Siswa 


\section{PENDAHULUAN}

Perpustakaan SMA Negeri 1

Pekanbaru adalah perpustakaan sekolah yang merupakan bagian integral yang mendukung proses belajar mengajar. Tujuan penyelanggaraan Perpustakaan SMA Negeri 1 Pekanbaru ini adalah untuk dapat menimbulkan kecintaan murid-murid terhadap membaca, memperkaya pengalaman belajar muridmurid, menanamkan kebiasaan belajar mandiri, melatih murid dalam menyelesaikan tugas-tugas sekolah, dan dapat membantu murid-murid, guru dan anggota staf sekolah dalam mengikuti perkembangan ilmu pengetahuan dan teknologi.

Upaya mencapai tujuan tersebut dilakukan melalui kegiatan pelayanan informasi yang meliputi aspek-aspek: menghimpun, mengadakan, mengolah, menyimpan, dan menyebarkan informasi kepada seluruh siswa yang memerlukannya. Sejalan dengan tujuan di atas, maka Perpustakaan SMA Negeri 1 Pekanbaru mempunyai beberapa fungsi, salah satunya adalah sebagai pusat ilmu pengetahuan dan pendidikan.

Untuk menunjang pelayanan yang diberikan kepada siswa-siswa, guru, dan karyawan, perpustakaan harus didukung oleh fasilitas-fasilitas yang memadai. Fasilitas adalah segala sesuatu baik benda maupun jasa yang menyertai pelayanan yang diberikan oleh perusahaan baik perusahaan jasa, dagang maupun perusahaan industri. Fasilitas dapat juga diartikan sebagai sarana dan prasarana yang tersedia di lingkungan maupun di dalam kantor perusahaan, dimaksudkan untuk memberikan pelayanan maksimal agar konsumen atau pelanggan merasakan nyaman dan puas. Fasilitas merupakan faktor penunjang utama dalam kegiatan suatu produk.

$$
\text { Pelayanan yang ada di }
$$

perpustakaan SMA Negeri 1 Pekanbaru dilakukan untuk memudahkan siswa dalam mengakses informasi dan meminjam media pendidikan seperti buku, koran, majalah dan lain-lain. Perpustakaan SMA Negeri 1 Pekanbaru berupaya menyediakan informasi terbaru dan itu dilakukan agar siswa merasa puas, sehingga siswa akan berkunjung kembali.

Perpustakaan SMA Negeri 1 Pekanbaru menyediakan sarana dan prasarana yang memadai untuk penunjang kelancaran pelaksanaan tugas dan pemanfaatan perpustakaan yang optimal. Tetapi masih ditemukan beberapa keluhan yang disampaikan oleh siswa, seperti adanya buku yang tidak memiliki sampul atau sampul buku yang lepas, halaman buku yang kurang. Sementara kecepatan pelayanan, keamanan dan perhatian atau keramahan karyawan juga perlu mendapat perhatian pengelola perpustakaan refrensi karena faktorfaktor tersebut dapat mempengaruhi kepuasan siswa yang berkunjung.

Menurut Parasuraman dalam Tjiptono (2012:26) faktor utama yang mempengaruhi pelayanan atau jasa adalah jasa yang diharapkan dan jasa yang di terima. Apabila jasa yang diterima konsumen sama dengan yang di harapkan atau bahkan lebih baik, maka di persepsikan bahwa kualitas jasa tersebut baik atau positif dan demikian pula sebaliknya. Oleh karena itu, baik tidaknya kualitas jasa atau pelayanan sangat di pengaruhi oleh kemampuan dari penyedia jasa dalam memenuhi harapan konsumen secara konsisten.

Menurut Kotler dalam Sardiman (2011: 111) kepuasan pelanggan sebagai perasaan senang atau kecewa seseorang yang berasal dari perbandingan antara kesannya terhadap kinerja (hasil) suatu produk dengan harapan-harapannya. Sedangkan 
Nasution (2004:120) menyebutkan Kepuasan adalah suatu keadaan yang dirasakan oleh seseorang setelah ia mengalami suatu tindakan atau hasil dari tindakan yang memenuhi harapannya.

Dengan demikian kepuasan pelanggan merupakan suatu kondisi atau perasaan yang ditunjukkan oleh pelanggan setelah menggunakan jasa atau pelayanan tersebut. Bila responnya positif, maka menunjukkan bahwa konsumen tersebut merasa puas dan akan datang atau berkunjung kembali. Namun sebaliknya, bila konsumen merasa tidak senang atau kecewa terhadap pelayanan yang diterimanya, maka menunjukkan bahwa konsumen tersebut tidak puas dan mempunyai image negative terhadap pelayanan tersebut.

Indikator kepuasan konsumen menurut Tjiptono (2004:62) adalah empat, yakni:

a. Penyediaan layanan yang baik.

b. Karyawan cepat dalam menyelesaikan pekerjaan

c. Karyawan mampu mengetahui keinginan dan mendiagnosis hal yang harus dilakukan dengan cepat. d. Karyawan memberikan perhatian individu dengan baik kepada keluhan konsumen.

\section{Tujuan Penelitian}

1. Untuk mengetahui kualitas pelayanan perpustakaan menurut siswa SMA N 1 Pekanbaru.

2. Untuk mengetahui fasilitas $\begin{array}{llll}\text { Perpustakaan } & \text { SMA } & \text { N } & 1\end{array}$ Pekanbaru.

3. Untuk mengetahui dan menganalisis pengaruh kualitas pelayanan dan fasilitas perpustakaan terhadap kepuasan siswa SMA N 1 Pekanbaru.

\section{METODOLOGI PENELITIAN}

Sesuai dengan permasalahan yang diteliti dan tujuan penelitian yang ditetapkan sebelumnya, maka jenis yang digunakan dalam penelitian ini adalah deskriptif. Penelitian deskriptif yang digunakan dengan teknik korelasional. Variabel penelitian meliputi dua bariabel bebas yaitu kualitas pelayanan $\left(\mathrm{X}_{1}\right)$ dan fasilitas perpustakaan $\left(\mathrm{X}_{2}\right)$ dan variabel terikatnya adalah kepuasan siswa (Y). Untuk melihat hubungan di atas dapat dilihat pada gambar model masalah di bawah ini:

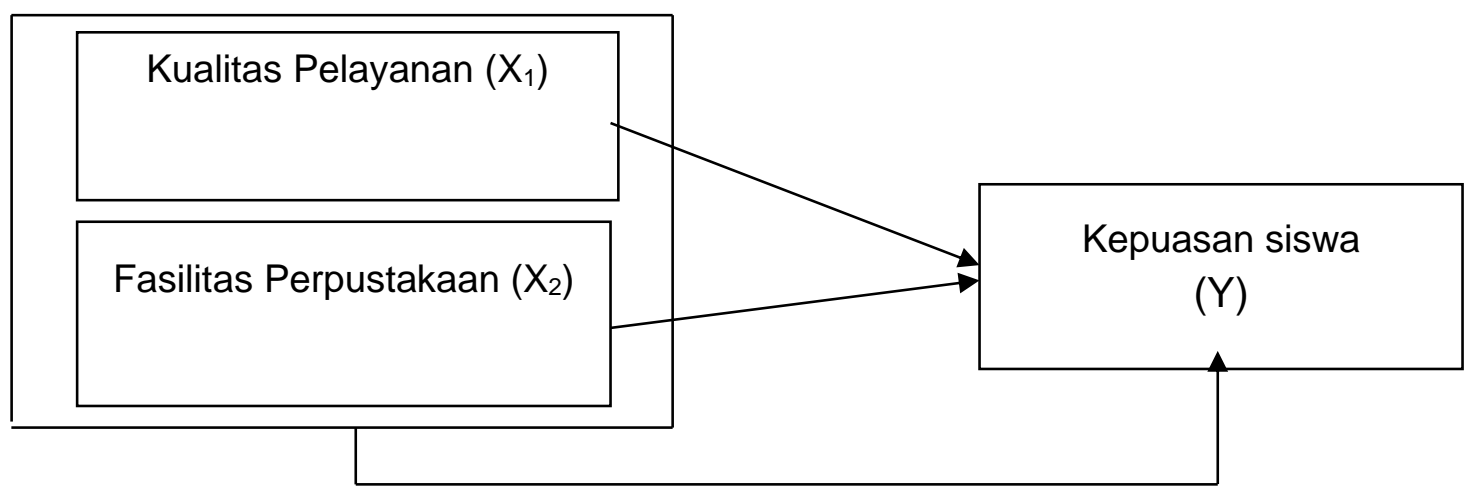

Gambar 2. Konstelasi Hubungan Antar Variabel

Di dalam pengambilan sampel, penulis menggunakan metode simple random sampling. Menurut Sugiyono
(2010:118) Simple random sampling adalah pengambilan anggota sampel dari populasi secara acak tanpa 
memperhatikan strata yang ada dalam populasi itu. Dengan demikian setiap anggota populasi mempunyai kesempatan yang sama untuk dipilih sebagai sampel.

Sedangkan penentuan jumlah
sampel dalam penelitian ini menggunakan rumus Slovin sebagai berikut :

$$
\mathrm{n}=\frac{\mathrm{N}}{1+\mathrm{N}(\mathrm{e})^{2}}
$$

Dimana:

$$
\begin{array}{ll}
\mathrm{n} & \text { : Ukuran sampel } \\
\mathrm{N} & \text { : Ukuran populasi } \\
\mathrm{e} & \text { : Taraf Kesalahan } \\
& \text { Sehingga jumlah sampel }
\end{array}
$$

menjadi:

$$
\begin{aligned}
& \mathrm{n}=\frac{979}{1+979(10 \%)^{2}} \\
& \mathrm{n}=90,73
\end{aligned}
$$

Dengan demikian, ukuran sampel dalam penelitian ini sebanyak 90,73. Maka dibulatkan menjadi 91 responden. Pengambilan sampel berasal dari siswa yang ditemui dilokasi perpustakaan SMA Negeri 1 Pekanbaru. Teknik pengumpulan data yang dipakai dalam penelitian ini adalah Daftar angket (Quisioner) dan dokumentasi, angket ditujukan kepada siswa-siswa SMA Negeri 1 Pekanbaru yang mengunjungi perpustakaan. Angket yang ini sebelumnya dirancang dan disusun sedemikian rupa untuk menghasilkan beberapa pertanyaan yang relevan dengan permasalahan penelitian, sehingga dapat diperoleh gambaran mengenai kepuasan siswa dari pelayanan dan fasilitas yang ada di perpustakaan.

Analisa data yang dilakukan pada penelitian ini adalah menggunakan analisa kuantitatif yaitu dengan suatu model untuk mengukur kualitas pelayanan dan fasilitas terhadap kepuasan siswa. Untuk pengujiannya dianggap kepuasan siswa (Y) dipengaruhi oleh kualitas pelayanan dan fasilitas perpustakaan (X). Disini dapat dimasukkan ke dalam regresi berganda dengan bentuk persamaan matematik.

$$
\begin{aligned}
& \mathrm{Y}=\mathrm{a}+\mathrm{bx} 1+\mathrm{bx} 2+\varepsilon \\
& \text { Dimana }: \mathrm{Y}=\text { Kepuasan }
\end{aligned}
$$

Siswa

regresi

Pelayanan

$$
\begin{aligned}
& \mathrm{a}=\text { Konstanta } \\
& \mathrm{b}=\text { Koefisien }
\end{aligned}
$$

Perpustakaan

$$
\mathrm{X} 1=\text { Kualitas }
$$$$
\mathrm{X} 2=\text { Fasilitas }
$$

$$
\begin{array}{ll}
\varepsilon & \quad \text { Error } \\
& \text { (kesalahan } \\
& \text { pengganggu })
\end{array}
$$

\section{Uji Persyaratan Untuk Analisis}

Adapun alat analisis yang digunakan, antara lain :

a. Uji Reliabilitas

b. Uji Validitas

\section{Uji Regresi Berganda}

Sebelum dilakukan pengujian analisis regresi linier berganda terhadap hipotesis penelitian, maka terlebih dahulu perlu dilakukan suatu pengujian asumsi klasik atas data yang akan diolah sebagai berikut :
a. Uji Normalitas
b. Uji Heteroskedastisitas
c. Uji Autokorelasi
3. Uji Hipotesis
a. Uji koefisien determinasi $\left(\mathrm{R}^{2}\right)$
b. Uji Parsial (uji t)
c. Uji Simultan (Uji Statistik F)

\section{HASIL PENELITIAN DAN PEMBAHASAN}

Permasalahan pokok dari penelitian ini adalah untuk mengetahui pengaruh kualitas pelayanan dan fasilitas perpustakaan terhadap kepuasan siswa SMAN 1 Pekanbaru. pada bab ini akan dipaparkan penelitian yang diperoleh, dimana hasil dari pembahasan selanjutnya disajikan sebagai acuan dalam mengambil 
kesimpulan. Untuk mengetahui hal tersebut akan dibahas secara berturutturut mengenai gambaran tentang data penelitian, analisis statistik deskriptif, pengujian hipotesis, hasil penelitian dan pembahasannya.

\section{Uji Realibilitas dan Validitas Data}

Kemudian untuk lebih jelas mengenai data yang dianalisis, maka terlebih dahulu dilakukan analisis uji realibiitas dan validitas yang kemudian setelah benar-benar valid baru data yang diteliti layak untuk dianalisis dan diuji hipotesisnya.

\section{a. Uji Realibilitas}

Realibilitas suatu instrumen yang menunjukkan konsistensi sebuah data, oleh karena itu instrumen yang reliabel berarti dapat digunakan untuk mengukur hal yang sama pada waktu berbeda dengan memberikan hasil yang sama. Uji realibilitas ini akan dilakukan pada butir-butir pertanyaan yang telah memiliki kevalidan pada uji validitas sebelumnya. Dengan demikian, jumlah butir pertanyaan yang dapat diuji reliabilitas ini adalah sebanyak 46 butir pertanyaan .

Pengujian realibilitas dilakukan dengan menggunakan formula Alpha Cronboach. Dimana hasil ujinya dapat dilihat pada tabel berikut:

Tabel 2. Hasil Uji Realibilitas Instrumen Penelitian Variabel (X) dan (Y)

\begin{tabular}{|c|c|c|}
\hline Variabel & Koefisien Alpha & Keterangan \\
\hline $\mathrm{X} 1$ & 0,910 & Reliabel \\
\hline $\mathrm{X} 2$ & 0,874 & Reliabel \\
\hline $\mathrm{Y}$ & 0,721 & Reliabel \\
\hline
\end{tabular}

Sumber : Data Olahan 2018

Menurut Priyanto (2008 : 26) bahwa realibitas kurang dari 0,6 adalah kurang baik, sedangkan 0,7 dapat diterima dan di atas 0,8 adalah baik. Hasil uji realibilitas yang disajikan pada tabel di 2 menunjukkan bahwa nilai koefisiennya di atas 0,8 berarti baik sehingga instrumen variabel kualitas pelayanan (X1) dan fasilitas perpustakaan (X2) yang digunakan dinyatakan reliable. Sedangkan instrument variabel kepuasaan siswa (Y) memiliki nilai koefisien alpha lebih dari 0,7 berarti instrumen yang digunakan reliable dapat diterima.

\section{b. Uji Validitas}

Pada perhitungan validitas yang terdapat pada lampiran 4 dapat disimpulkan bahwa dari 25 butir pertanyaan variabel kualitas pelayanan (X1) dan 15 butir pertanyaan untuk variabel fasilitas perpustakaan (X2), sementara variabel kepuasaan siswa (Y) sebanyak 6 butir pertanyaan. Dari pengolahan data diketahui seluruh pertanyaan yang disajikan telah valid dengan nilai $\mathrm{r}_{\text {hitung }}>\mathrm{r}_{\text {tabel }}$ sehingga pertanyaan tersebut layak untuk dianalisis. Dimana nilai $r_{\text {tabel }}$ sebesar 0,128 , sehingga apabila nilai $r_{\text {tabel }}$ lebih kecil maka pertanyaan yang diajukan tidak valid dan begitu juga sebaliknya jika nilai $r_{\text {tabel }}$ lebih besar maka pertanyaan yang diajukan dapat diterima untuk dianalisis. Untuk lebih jelasnya dapat dilihat pada tabel berikut

Berdasarkan distribusi hasil pengolahan data pada tabel validitas data pada masing-masing variabel penelitian, maka jelaslah bahwa seluruh pertanyaan dari variabel kualitas pelayanan (X1) dan variabel fasilitas perpustakaan (X2) serta variabel 
kepuasaan siswa (Y) sudah valid dan seluruh pertanyaan layak untuk diajukan serta dianalisis.

\section{Pengujian Persyaratan Analisis Data}

Data dan informasi yang diperoleh selama penelitian melalui proses pengumpulan data dan pengolahan awal merupakan dasar bagi pengujian hipotesis, pembahasan masalah dan penarikan kesimpulan.

\section{Hasil Uji Normalitas}

Uji normalitas data dalam penelitian ini dilakukan dengan bantuan alat uji statistic normal probability plot (normal P-P Plot) terhadap masingmasing variabel. Jika sebaran data berada di sekitar garis diagonal maka dapat ditarik kesimpulan bahwa data terdistribusi dengan normal. Dapat dilihat pada gambar berikut :

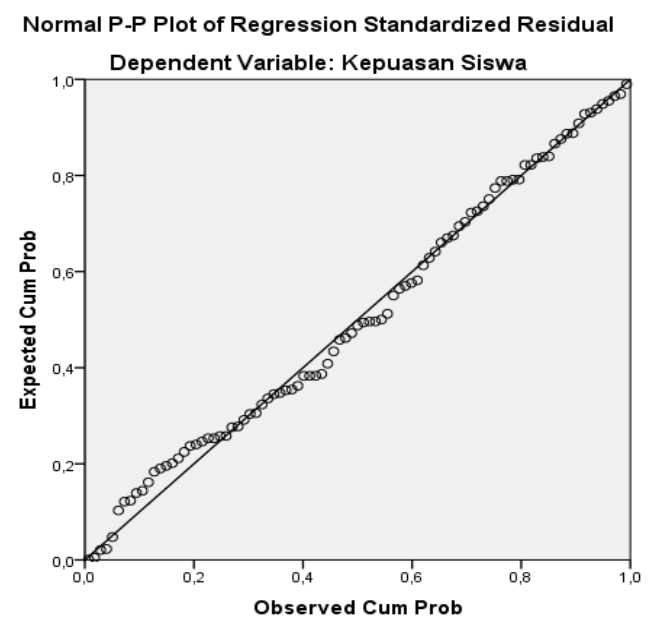

Gambar 3 Normalitas

Sumber : Data Olahan 2018

Hasil uji normal P-P Plot (normal probability plot) untuk variabel independent dan dependen dapat dilihat pada gambar di atas. Gambar tersebut terlihat titik-titik menyebar disekitar garis diagonal, serta penyebarannya mendekati garis diagonal maka model regresi ini memenuhi asumsi normalitas atau dikatakan normal.

\section{Hasil Uji Multikolinearitas}

Pengujian multikolinearitas
dilakukan untuk menjelaskan kemungkinan terdapatnya hubungan antara variabel independent yang satu dengan variabel independent yang lain. Untuk mendeteksinya, dalam penelitian ini dilakukan dengan melihat nilai Variance Inflation Factor (VIF) untuk tiap-tiap variabel independen. Jika VIF lebih besar dari 5 maka variabel tersebut dikatakan mempunyai persoalan multikolinearitas dengan variabel lainnya (Santoso, 2007). Hasil uji multikolinearitas dalam penelitian ini dapat dilihat pada tabel berikut:

Tabel 3. Hasil Uji Multikolinearitas

\begin{tabular}{|c|r|r|c|}
\hline Variabel & $\begin{array}{c}\text { Toleranc } \\
\mathrm{e}\end{array}$ & VIF & Kesimpulan \\
\hline $\begin{array}{c}\text { Kualitas } \\
\text { Pelayan } \\
\text { an }\end{array}$ & 5 & $\begin{array}{r}1,27 \\
4\end{array}$ & $\begin{array}{c}\text { Bebas } \\
\text { multikolinear } \\
\text { itas }\end{array}$ \\
\hline $\begin{array}{c}\text { Fasilitas } \\
\text { Pelayan } \\
\text { an }\end{array}$ & 5 & $\begin{array}{r}1,27 \\
\text { Bebas } \\
\text { multikolinear } \\
\text { itas }\end{array}$ \\
\hline
\end{tabular}

Sumber : Data Olahan, 2018

Berdasarkan Tabel 3 semua nilai

VIF variabel independent tersebut lebih kecil dari 5. maka dapat disimpulkan bahwa model regresi ini bebas dari gangguang multikolinearitas dan dapat digunakan dalam penelitian.

\section{Hasil Uji Heteroskedastisitas}

Pengujian heteroskedastisitas dalam model regresi dilakukan untuk mengetahui apakah model regresi terjadi ketidaksamaan varian dari nilai residual penelitian. Untuk membuktikan ada tidaknya gangguan heteroskedastisitas dapat dilihat melalui pola diagram (scatterplot). Jika scatterplot membentuk pola tertentu maka regresi mengalami gangguan heteroskedastisitas. Sebaliknya jika scatterplot tidak membentuk pola tertentu (menyebar) maka regresi tidak mengalami heteroskedastisitas. gangguan 


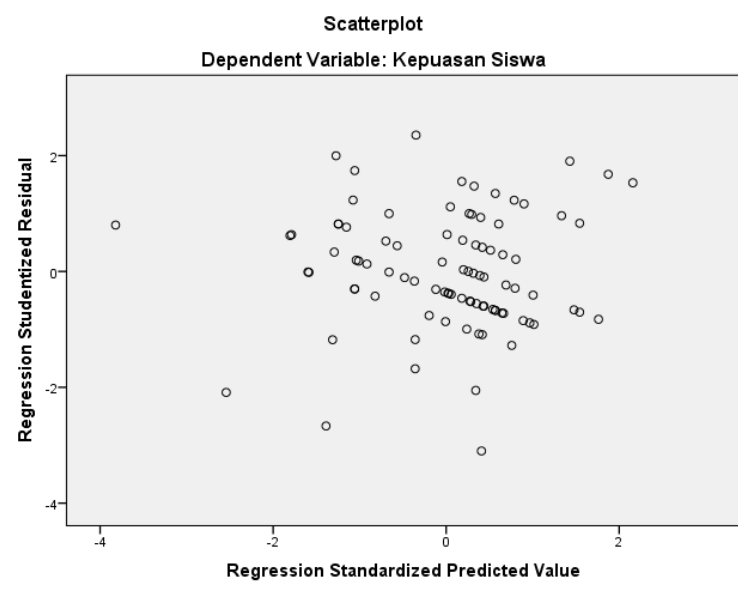

Gambar 4 Scatterplot

Sumber : Data Olahan 2018

Dari grafik scatterplot di atas, terlihat bahwa titik-titik menyebar secara acak, tidak membentuk suatu pola tertentu yang jelas, serta tersebar di atas dan di bawah angka nol (0) pada sumbu Y. Oleh karena itu, dapat disimpulkan bahwa model regresi dalam penelitian ini bebas heteroskedastisitas.

\section{Hasil Uji Autokorelasi}

Pengujian autokorelasi dalam penelitian ini dapat dilihat dari tabel dibawah :

Tabel 4. Hasil Uji Autokorelasi

\section{Model Summaryb}

\begin{tabular}{|c|c|c|c|c|}
\hline $\begin{array}{l}\text { Mod } \\
\text { el }\end{array}$ & R & $\begin{array}{c}\mathrm{R} \\
\text { Squar } \\
\mathrm{e}\end{array}$ & $\begin{array}{c}\text { Adju } \\
\text { sted } \\
\text { R } \\
\text { Squa } \\
\text { re }\end{array}$ & $\begin{array}{c}\text { Std. } \\
\text { Error } \\
\text { of the } \\
\text { Estimat } \\
\text { e }\end{array}$ \\
\hline 1 & $\begin{array}{r}75 \\
\mathrm{a}\end{array}$ & , 225 & ,208 & ,33400 \\
\hline
\end{tabular}

Sumber : Data Olahan 2018

Dari Tabel 4 diperoleh angka Durbin-Watson 1,909. angka tersebut menunjukkan bahwa model regresi pada penelitian ini bebas dari autokorelasi, karena angka tersebut berada di daerah No Autocorrelation $(-2<$ atau $<2)$.

\section{Hasil Pengujian Hipotesis Penelitian}

Sebagaimana yang telah dijelaskan pada bab sebelumnya bahwa untuk menguji hipotesis dalam penelitian ini digunakan analisis regresi berganda dengan bantuan program SPSS Versi 20.00. Model penelitian, seperti yang telah dijelaskan sebelumnya yaitu model regresi linear berganda, dengan model:

$$
\mathrm{Y}=\alpha+\beta_{1} \mathrm{X}_{1}+\beta_{2} \mathrm{X}_{2}+\mathrm{e}
$$

Metode analisis yang digunakan adalah metode enter yaitu metode analisis biasa dimana semua variabel independen termasuk dependen sebagai prediktor tanpa memandang apakah variabel tersebut berpengaruh besar atau kecil pada variabel dependen.

Persamaan regresi linear berganda sebagai berikut :

$$
\begin{gathered}
\mathrm{R}_{\mathrm{it}}=\beta_{0}+\beta_{1} \text { Kualitas Pelayanan }_{\mathrm{it}}+\beta_{2} \\
\text { Fasilitas Perpustakaan }_{\mathrm{it}}+\varepsilon_{\mathrm{it}}
\end{gathered}
$$

Atau disederhanakan sebagai berikut :

$\mathrm{Y}=\mathrm{a}+\mathrm{b}_{1} \mathrm{X}_{1}+\mathrm{b}_{2} \mathrm{X}_{2}+\varepsilon$

$\mathrm{Y}=1.891+0.211 \mathrm{X}_{1}+0.328 \mathrm{X}_{2}+0.446$

Angka-angka dalam persamaan regresi linear berganda di atas dapat diartikan sebagai berikut :

1. Nilai konstanta (a) adalah 1.891; artinya jika kualitas pelayanan dan fasilitas perpustakaan bernilai di atas 0 (nol) maka nilai kepuasan siswa bernilai positif.

2. Nilai koefisien regresi variabel kualitas pelayanan $\left(b_{1}\right)$ bernilai positif (0.211) artinya; setiap peningkatan kualitas pelayanan sebesar 0.211 poin,- maka kepuasan siswa akan berubah positif, dengan asumsi variabel lain bernilai tetap.

3. Nilai koefisien regresi variabel fasilitas perpustakaan $\left(\mathrm{b}_{2}\right)$ bernilai positif (0.328) artinya; setiap peningkatan fasilitas perpustakaan sebesar 0,328 poin,- maka kepuasan siswa akan berubah positif, dengan asumsi variabel lain bernilai tetap. 
4. Nilai standar error (e) didapatkan sebesar 0.466

Dalam pembahasan ini akan menguji apakah hasil hipotesis-hipotesis yang telah dibahas sebelumnya berpengaruh signifikan atau tidak terhadap nilai perusahaan (variabel dependent). Berdasarkan kriteria hasil pengujian ini dapat dilakukan dengan 3 (dua) cara yaitu sebagai berikut :

\section{Koefisien Determinasi}

Koefisien determinasi digunakan untuk melihat seberapa besar variabel independen yang digunakan dapat menjelaskan variabel dependen. Dalam penelitian yang berhubungan dengan ilmu sosial, biasanya digunakan Adjusted R Square atau $\mathrm{R}^{2}$.

Berdasarkan hasil pengolahan data, variabel independent dapat menjelaskan variabel dependent sebesar $22 \%$ sedangkan sisanya $78 \%$ dijelaskan oleh variabel lain diluar variabel yang digunakan. Ini berarti, variabel independent yang digunakan tidak sesuai karena tidak dapat menjelaskan lebih dari $50 \%$ variabel dependen.

\section{Uji Parsial (t)}

Pengujian dapat dilakukan dengan membandingkan nilai $t_{\text {hitung }}$ dengan nilai $t_{\text {tabel }}$ serta membandingkan nilai signifikan $\mathrm{t}$ dengan level of significant ( $\alpha)$. Nilai dari level of significant yang digunakan dalam penelitian ini adalah 5 persen $(0,05)$. Apabila sig t lebih besar dari 0,05 maka $\mathrm{H}_{0}$ diterima. Demikian pula sebaliknya jika sig t lebih kecil dari 0,05, maka $\mathrm{H}_{0}$ ditolak. Bila $\mathrm{H}_{0}$ ditolak ini berarti ada hubungan yang signifikan antara variabel independen terhadap variabel dependen (Ghozali, 2013:40)

Hasil pengujian hipotesis untuk dapat dilihat pada tabel berikut :

Tabel 5. Hasil Pengujian Hipotesis

\begin{tabular}{|c|c|c|c|c|c|}
\hline \multirow{2}{*}{ Variabel } & \multicolumn{2}{|c|}{ Berdasarkan Uji t } & \multicolumn{2}{|c|}{$\begin{array}{l}\text { Berdasarkan } \\
\text { Signifikansi }\end{array}$} & \multirow{2}{*}{$\begin{array}{c}\text { Hasil H }_{1} \\
\text { Diterima/Ditolak }\end{array}$} \\
\hline & $t_{\text {hitung }}$ & $\mathrm{t}_{\text {tabel }}$ & $\alpha$ & Sig. & \\
\hline $\mathrm{X} 1$ & 1.997 & 1.590 & .000 & 0.05 & Diterima \\
\hline $\mathrm{X} 2$ & 3.191 & 1.590 & .000 & 0.05 & Diterima \\
\hline $\mathrm{R}^{2}$ & \multicolumn{2}{|c|}{ Adjusted $\mathrm{R}^{2}$} & & $\overline{F_{\text {hitung }}}$ & $\mathrm{F}_{\text {tabel }}$ \\
\hline 0,225 & \multicolumn{2}{|c|}{0,208} & & 12.789 & 4.02 \\
\hline
\end{tabular}

Sumber : Data Olahan, 2018.

a. Hasil Pengujian Hipotesis Pertama $\left(\mathrm{H}_{1}\right)$

Pada Tabel 5 hasil pengujian Hipotesis Pertama $\left(\mathrm{H}_{1}\right)$ menunjukkan bahwa variabel kualitas pelayanan thitung $(1.997)>t_{\text {tabel }}(1.590)$ dan signifikansi $(0.000)>$ alpha $(\alpha=0.05)$, maka hasil hipotesis pertama $\left(\mathrm{H}_{1}\right)$ diterima, sehingga dapat disimpulkan bahwa kualitas pelayanan berpengaruh signifikan terhadap kepuasan siswa.

Terdapat pengaruh yang signifikan antara variabel kualitas pelayanan terhadap kepuasan siswa menunjukkan bahwa kualitas pelayanan mempunyai peranan penting dalam meningkatkan kepuasan siswa maka dengan kualitas pelayanan yang baik akan memberikan dampak terhadap kepuasan siswa.

b. Hasil Pengujian Hipotesis Kedua $\left(\mathrm{H}_{2}\right)$ Hasil pengujian hipotesis kedua ini dapat dilihat pada tabel di atas menunjukkan bahwa variabel fasilitas perpustakaan $t_{\text {hitung }}(3.191)>t_{\text {tabel }}$ (1.590) dan signifikansi $(0.000)<$ alpha 
$(\alpha=0.05)$, maka hasil hipotesis kedua $\left(\mathrm{H}_{2}\right)$ diterima, sehingga dapat disimpulkan bahwa variabel fasilitas perpustakaan berpengaruh signifikan terhadap kepuasaan siswa.

Hasil ini menunjukkan bahwa hipotesis kedua yakni variabel fasilitas perpustakaan memiliki pengaruh yang signifikan terhadap kepuasan siswa. Dimana dengan fasilitas perpustakaan yang baik dimiliki SMA N 1 Kota Pekanbaru akan memberi gambaran terhadap kepuasan siswa untuk masa mendatang, sehingga kepuasaan siswa menjadi semakin tinggi.

c. Hasil Pengujian Hipotesis Ketiga $\left(\mathrm{H}_{3}\right)$

Dari hasil yang ditampilkan pada tabel di atas menjelaskan bahwa secara bersama-sama kualitas pelayanan dan fasilitas perpustakaan memberi pengaruh yang signifikan terhadap kepuasan siswa.

3. Uji F

Untuk menguji hipotesis ketiga digunakan uji $\mathrm{F}$ atau uji serempak sebagai berikut:

Tabel 6. Anova/Uji F

\begin{tabular}{|c|c|c|c|c|c|}
\hline Model & $\begin{array}{c}\text { Sum } \\
\text { of } \\
\text { Square } \\
\text { s }\end{array}$ & $\begin{array}{l}\mathrm{D} \\
\mathrm{f}\end{array}$ & $\begin{array}{c}\text { Mea } \\
\mathrm{n} \\
\text { Squ } \\
\text { are }\end{array}$ & $\mathrm{F}$ & Sig \\
\hline $\begin{array}{l}1 \text { Regress } \\
\text { ion }\end{array}$ & 2,853 & 2 & $\begin{array}{r}1,42 \\
7\end{array}$ & $\begin{array}{r}12,7 \\
89\end{array}$ & $\begin{array}{r}, 00 \\
0^{\mathrm{b}}\end{array}$ \\
\hline $\begin{array}{l}\text { Residua } \\
1\end{array}$ & 9,817 & $\begin{array}{l}8 \\
8\end{array}$ & ,112 & & \\
\hline Total & 12,670 & 0 & & & \\
\hline
\end{tabular}

Sumber: Olahan, 2018

Berdasarkan Tabel 6 diketahui bahwa $\mathrm{F}$ hitung sebesar 12,789 sedangkan $\mathrm{F}$ tabel $=3,13$ yang dapat dilihat pada $\alpha=0,05$ (lihat Lampiran 5) dengan tingkat signifikan 0,000 dari perhitungan didapat nilai $\mathrm{F}$ hitung $=$ $12,7891>$ dari " $F$ " tabel $=3,13$ Oleh karena jauh dibawah 0,05 probabilitasnya maka tolak Ho (Terima H1). Kualitas Pelayanan dan Fasilitas Perpustakaan berpengaruh secara bersamaan (simultant) terhadap Kepuasan Siswa SMA Negeri 1 Kota Pekanbaru.

\section{Pengaruh Kualitas Pelayanan dan Fasilitas PersputakaanTerhadap Kepuasan Siswa \\ Perpustakaan SMA Negeri 1}

Pekanbaru memberikan pelayanan kepada siswa-siswi dan guru untuk membaca koleksi buku-buku dan dokumen-dokumen lainnya ditempat dan memberikan pelayanan peminjaman buku. Pelayanan perpustakaan dibuka setiap hari SeninSabtu dengan waktu pelayanan sebagai berikut: Senin - Kamis, pukul 07.0015.00 dan Jumat pukul 07.00-11.00. Perpustakaan SMA Negeri 1 Pekanbaru menyediakan layanan peminjaman koleksi dengan ketentuan sebagai berikut : Guru, lama peminjaman 1 bulan, jumlah buku 5 eks, buku bisa diperpanjang selama 1 minggu. Karyawan, lama peminjaman 1 minggu, jumlah buku 2 eks, buku bisa diperpanjang 1 minggu. Siswa lama peminjaman 1 minggu, jumlah buku 4 eks, buku yang dipinjam bisa diperpanjangan selama 1 minggu.

Kepuasan siswa merupakan hal yang bisa membuat kepercayaan siswa terhadap perpustakan meningkat. Berdasarkan hasil uji hipotesis dan analisis regresi dalam penelitian ini, menunjukkan bahwa variabel kualitas pelayanan dan fasilitas perpustakaan secara simultan atau bersama-sama berpengaruh signifikan terhadap kepuasan siswa dan pengaruhnya adalah positif. Hal ini berarti bahwa hubungan antara kedua variabel independen tersebut terhadap variabel dependen memiliki pengaruh secara simultan atau bersama-sama. 


\section{Pengaruh Kualitas Pelayanan Terhadap Kepuasan Siswa}

Berdasarkan hasil uji hipotesis ditemukan bahwa variabel kualitas pelayanan dalam penelitian ini memiliki pengaruh yang signifikan terhadap kepuasan siswa khususnya di perpustakaan SMA Negeri 1 Kota Pekanbaru, dan pengaruh dari variabel kualitas pelayanan terhadap kepuasan siswa adalah signifikan dan arahnya positif. Hasil penelitian ini memperkuat penelitian sebelumnya yaitu Haryanto (2013), dimana dalam penelitian tersebut ditemukan bahwa variabel kualitas memiliki pengaruh signifikan dan positif terhadap kepuasan masyarakat pada kantor samsat manado. Dan pada penelitian Runtunuwu (2014), didalam penelitian ini menunjukan bahwa variabel kualitas pelayanan berpengaruh signifikan terhadap kepuasan pengguna Cafe dan Resto Cabana Manado. Hal ini berarti bahwa pengguna sangat mementingkan kualitas pelayanan yang diterima di Cafe dan Resto Cabana Manado. (Budiyanto (2013), penelitian ini bahwa pengujian hipotesis antara variabel kualitas pelayanan dan fasilitas berpengaruh signifikan dan positif terhadap kepuasan siswa di SMA Negeri 1 Kota Pekanbaru. Hasil ini mengindikasikan bahwa semakin baik kualitas pelayanan dan fasilitas perpustakaan yang diberikan perusahaan akan meningkatkan kepuasan siswa yang memanfaatkan jasa perpustakaan sekolah untuk memperoleh informasi ilmu pengetahuan. Implikasi dari penelitian ini, menyebabkan perpustakaan SMA Negeri 1 Kota Pekanbaru harus terus meningkatkan kualitas pelayanan untuk meningkatkan kepuasan siswa, sebab menjadi suatu ukuran keberhasilan perpustakaan dalam mencapai tujuannya.

\section{Pengaruh Fasilitas Perpustakaan Terhadap Kepuasan Siswa}

Berdasarkan hasil uji hipotesis ditemukan bahwa variabel fasilitas perpustakaan dalam penelitian ini memiliki pengaruh yang signifikan terhadap kepuasan siswa SMA Negeri 1 Kota Pekanbaru, dan pengaruh dari variabel fasilitas perpustakaan terhadap kepuasan siswa adalah signifikan dan arahnya positif. Hasil penelitian ini memperkuat penelitian sebelumnya yaitu Mongkaren (2013) dan Lumentut dan Palendeng (2014), dimana dalam penelitian-penelitian tersebut ditemukan bahwa variabel fasiliatas memiliki pengaruh signifikan dan positif terhadap kepuasan konsumen. Penelitian pertama memfokuskan pada fasilitas pengguna jasa Rumah Sakit Advent Manado, sedangkan pada penelitian kedua fasilitas terhadap MCDONALD'S Manado. Implikasi dari penelitian ini, menyebabkan perpustakaan SMA Negeri 1 Kota Pekanbaru harus terus meningkatkan kepuasan siswa dan kemampuan pegawai perpustakaan dalam menjaga fasilitas perpustakaan kepada para siswa yang akan memicu kepuasan siswa SMA Negeri 1 Kota Pekanbaru secara berkelanjutan dan akan berdampak pada keinginan siswa untuk terus memanfaatkan perpustakaan sebagai tempat mencari informasi ilmu pengetahuan dilihat dari segala aspek dari fungsi perpustakaan.

\section{SIMPULAN DAN SARAN}

Berdasarkan hasil pengujian hipotesis dan pembahasan hasil penelitian dapat ditarik kesimpulan dan saran sebagai berikut :
1. Hipotesis Pertama $\left(\mathrm{H}_{1}\right)$ menunjukkan bahwa variabel kualitas pelayanan, maka hasil hipotesis pertama dapat disimpulkan bahwa kualitas 
pelayanan berpengaruh signifikan terhadap kepuasan siswa

2. Hipotesis kedua menunjukkan bahwa variabel fasilitas perpustakaan maka hasil hipotesis kedua, sehingga dapat disimpulkan bahwa variabel fasilitas perpustakaan berpengaruh signifikan terhadap kepuasaan siswa.

3. Kualitas Pelayanan dan Fasilitas Perpustakaan berpengaruh secara serempak (simultant) terhadap Kepuasan Siswa SMA Negeri 1 Kota Pekanbaru.

4. Koefisien determinasi variabel indenpendent terhadap variabel dependent sebesar 22\% sedangkan sisanya $78 \%$ dijelaskan oleh variabel lain diluar variabel yang digunakan. Ini berarti, variabel independent yang digunakan tidak sesuai karena tidak dapat menjelaskan lebih dari $50 \%$ variabel dependen.

\section{Saran}

Berdasarkan hasil penelitian dan pembahasan yang telah dijelaskan maka dibuat saran sebagai berikut:

1. Bagi petugas perpustakaan

Petugas perpustakaan hendaknya lebih teliti kembali dalam pencatatan jumlah permintaan buku yang dibutuhkan sehingga jumlah buku mata pelajaran merata ke setiap siswa..

Hendaknya jumlah meja kursi baca ditambahkan lagi dan ditata lebih rapi lagi.

Petugas perpustakaan memberikan kegiatan bimbingan belajar dengan siswa-siswi. Kegiatan itu seperti membantu mengarahkan pencarian literatur yang dipakai saat guru memberikan tugas di perpustakaan maupun belajar kelompok di perpustakaan.

2. Bagi sekolah
Fasilitas perpustakaan di SMA Negeri 1 Kota Pekanbaru sudah baik dan dapat diterima pengunjung perpustakaan sehingga perlu dipertahankan atau bahkan ditingkatkan.

Kepuasaan siswa yang sudah baik perlu ditingkatkan dengan menambah beberapa fasilitas pendukung perpustakaan yang lebih modern sesuai perkembangan zaman

3. Bagi peneliti selanjutnya

Di harapkan bagi peneliti selanjutnya untuk dapat melanjutkan penelitian ini dapat melanjutkan penelitian ini dengan menambah variabel ataupun dengan menggunakan analisis data yang berbeda

\section{DAFTAR PUSTAKA}

Arikunto, Suharsimi. (2010). Prosedur Penelitian: Suatu Pendekatan Praktek. Jakarta: Rineka Cipta.

Assegaff, Mohammad. (2009). "Pengaruh Kualitas Pelayanan Terhadap Kepuasan Pelanggan" Jurnal EKOBIS, Vol. 10, No. 2 Tahun 2009.

Bafadal, Ibrahim. (2014). Pengelolaan Perpustakaan Sekolah, Jakarta, Bumi Aksara

Danang, Sunyoto. (2015)., Manajemen Pemasaran Jasa,Yogyakarta: CAP.

Emmywati, (2016). Jurnal Pengaruh Kualitas Layanan Yang Terdiri Dari Kenyamanan, Keamanan, Kemudahan Dan Fasilitas Terhadap Kepuasan Konsumen Pada Galeri Seni Dan Pusat Meditation Ponorogo Jawa Timur 
Ghozali, Imam. (2012). Aplikasi Analisis Multivariat dengan program SPSS. Semarang: Badan Penerbit Universitas Diponegoro

Hardiansyah. (2011). Kualitas Pelayanan Publik. Yogyakarta: Gava Media.

Lovelock, Christopher., Wirtz, Jochen., and, Mussry,Jacky. (2011). Pemasaran Jasa: Manusia, Teknologi, dan Strategi (Perspektif Indonesia).Jakarta: Erlangga

Lupyoadi, Rambat, (2001). Manajemen Pemasaran Jasa, Jakarta : Salemba Empat.

Mufid. (2011). Tesis Pengaruh Mutu Layanan Terhadap Kepuasan Pemustaka: Studi Kasus Di Perpustakaan Pusat UIN Maulana Malik Ibrahim Malang.

Nasution, M.N. (2004). Manajemen Jasa Terpadu, Jakarta: Ghalia Indonesia.

Nugroho, Wahyu. (2011). Riset Pemasaran dan Konsumen. Bogor: IPB Press.

Prastowo, Andi (Ed). (2012). Manajemen Perpustakaan Sekolah Profesional. Yogyakarta: DIVA Press.

Solomon, M.R. \& Rabolt, N. (2009). Consumer Behaviour in Fashion, 2nd.Edition. USA: Prentice Hall

Sugiyono. (2010). Metode Penelitian Kuantitatif Kualitatif dan $R \& D$, Bandung: Alfabeta.
Supranto, J. (2001) Pengukuran Tingkat Kepuasan Pelanggan Untuk Menaikan Pangsa Pasar.

Supriyanto (Ed). (2006). Aksentuasi Perpustakaan dan Pustakawan. Jakarta: Ikatan Pustakawan Indonesia.

Tjiptono, Fandy. (2004). Strategi Pemasaran. Yogyakarta; Andi.

Tjiptono, Fandy \& Candra, G. (2012). Service Management Meningkatkan Layanan Prima. Jakarta: Andi.

Utami, Pri dan Bakhtaruddin Nst. (2012). "Peran Perpustakaan Sekolah dalam Meningkatkan Minat Baca Siswa SDIT IQRA' Kota Solok". Dalam Jurnal Ilmu Informasi Perpustakaan dan Kearsipan Vol. 1, No.1. Hal 272. Padang: Universitas Negeri Padang.

Undang-Undang Republik Indonesia No. 43 Tahun 2007 tentang PerpustakaanSekolah. Jakarta: Kencana Prenada Media Group.

Zeithaml, Valerie, Bitner, Mary \& Gremler, Dwayne. (2009). Service Marketing. New York: The McGraw Hill Companies. 